\title{
IMPROVING THE MICROSTRUCTURE AND MECHANICAL PROPERTIES OF MAGNESIUM-ALLOY SHEETS WITH A NEW EXTRUSION METHOD
}

\author{
IZBOLJŠANJE MIKROSTRUKTURE IN MEHANSKIH LASTNOSTI \\ PLOČEVINE IZ Mg-ZLITINE Z NOVO METODO IZTISKAVANJA
}

\author{
Liwei Lu ${ }^{1}$, Zhenru Yin ${ }^{1}$, Yanfeng Liu ${ }^{1}$, Dandan Chen ${ }^{1}$, Chuming Liu ${ }^{2}$, \\ Zhiqiang $\mathbf{W u}^{1}$ \\ ${ }^{1}$ Hunan University of Science and Technology, Hunan Provincial Key Laboratory of High Efficiency and Precision Machining of \\ Difficult-to-Cut Material, Xiangtan, Hunan 411201, China \\ ${ }^{2}$ Central South University, School of Materials Science and Engineering, Changsha 410083, Hunan, China \\ cqullw@163.com,wuzq2009@163.com
}

Prejem rokopisa - received: 2017-05-19; sprejem za objavo - accepted for publication: 2017-06-22

doi:10.17222/mit.2017.059

\begin{abstract}
A new effective extrusion technique, including integrated direct extrusion and bending-shear deformation, was proposed to fabricate AZ31-magnesium-alloy sheets with high performance, and the grain refinement, texture and mechanical properties were further investigated. The results show that the new extrusion technique can noticeably refine the grain size from $240 \mu \mathrm{m}$ to $3.2 \mu \mathrm{m}$ at $563 \mathrm{~K}$, and the basal texture is also dramatically weakened, which can be attributed to a fully dynamic recrystallization triggered by a large shearing strain accumulated due to a bar-sheet deformation and continuous bending-shear deformation Consequently, the ductility significantly increases from $11.67 \%$ to $27.7 \%$, and the ultimate tensile stress can still keep a high value of $290 \mathrm{MPa}$, rendering this new technique an effective processing method for further tailoring of the microstructure and properties of $\mathrm{Mg}$-based alloys for a wide range of engineering applications.

Keywords: AZ31-Mg alloy, hot extrusion, microstructure, mechanical properties
\end{abstract}

Avtorji prispevka so raziskovali vpliv nove učinkovite tehnike iztiskavanja (ekstrudiranja) na lastnosti pločevine iz Mg zlitine AZ31. Pri tej tehniki sta združena postopka direktnega iztiskanja in upogibanja s strižno deformacijo (angl.: Direct Extrusion and Bending Shear; DEBS). Avtorji ugotavljajo, da je prišlo do udrobljenja mikrostrukture, raziskali pa so tudi teksturo in določili mehanske lastnosti tako izdelane pločevine. Rezultati raziskave so pokazali, da je nova tehnika ekstrudiranja opazno zmanjšala velikost kristalnih zrn iz $240 \mu \mathrm{m}$ na $3,2 \mu \mathrm{m}$ pri $563 \mathrm{~K}\left(290{ }^{\circ} \mathrm{C}\right)$, prav tako je občutno oslabela bazala tekstura, kar je pripisati popolni dinamični rekristalizaciji zaradi velike strižne deformacije nakopičene med preoblikovanjem okroglice $\mathrm{v}$ pločevino in neprekinjene upogibno-strižne deformacije. Posledično se je občutno povišala duktilnost iz $11,67 \%$ na $27,7 \%$ in natezna trdnost je še vedno ostala na visokem nivoju $290 \mathrm{MPa}$. Zato ta nova tehnika iztiskavanja lahko postane učinkovita procesna tehnologija za nadaljnje prilagajanje mikrostrukture in lastnosti Mg zlitin široki paleti inženirskih aplikacij.

Ključne besede: AZ31 magnezijeva zlitina, vroče ekstrudiranje, mikrostruktura, mehanske lastnosti

\section{INTRODUCTION}

The efforts to improve energy efficiency and develop low-density and high-specific-strength magnesium alloys for various structural applications in transportation vehicles are strongly driven by the development of lightweight construction. However, its application is still limited due to the hexagonal close-packed structure with poor slip systems at room temperature. ${ }^{1-3}$ To overcome this problem, many scholars paid more attention to the grain refinement using severe plastic-deformation (SPD) techniques. ${ }^{4,5}$ Nowadays, the most attractive SPD procedures are equal-channel angular pressing (ECAP), ${ }^{6,7}$ cyclic extrusion compression (CEC), ${ }^{8,9}$ high-pressure torsion (HPT) $)^{10,11}$ and accumulative roll bonding (ARB). ${ }^{12,13}$ A. Muralidhar et al. ${ }^{14}$ adopted four passes of ECAP via the $B_{\mathrm{c}}$ route for a magnesium alloy at a temperature of $573 \mathrm{~K}$. The average grain size was reduced from $31.8 \mu \mathrm{m}$ to $8 \mu \mathrm{m}$. J. B. Lin et al. ${ }^{15}$ used CEC to extrude the GW102 K alloy at $623 \mathrm{~K}$ with 8 passes. The elongation to failure was dramatically increased by 162.5 $\%$, and the yield strength (YS) and ultimate tensile strength (UTS) increased by $41.3 \%$ and $16.1 \%$, respectively. It should be noted that these techniques commonly require several passes before fine grains and a homogeneous strain can be obtained. Therefore, it is urgent to decrease the SPD passes to reduce the cost and increase the efficiency of practical processing of $\mathrm{Mg}$ alloys.

In the current study, AZ31-magnesium-alloy sheets are fabricated using a new extrusion method, integrating direct extrusion and bending shear (DEBS), which adds a successive bending-shear deformation to the conventional extrusion for further improving the microstructure and the basal texture. This deformation process can accumulate a large and homogeneous strain in the materials in a single pass, and the grains and basal texture of the AZ31-Mg-alloy sheets are prominently refined and weakened, respectively. Moreover, DEBS is proved 
to be a promising way to produce high-performance Mg-alloy sheets.

\section{EXPERIMENTAL PART}

A schematic diagram of the DEBS process is in Figure 1, which shows the configuration of a designed and manufactured DEBS die. For the sake of clarity, the characteristic zones of the extrusion deformation were divided into stages I, II, III, IV and V, representing the conical part, the forward-extrusion bar sheet, the first bending-shear zone, the second bending-shear zone, and the eventual forming stage, respectively. As for zone I, the forward-extrusion ratio and conical angle were $7.08^{\circ}$ and $60^{\circ}$, respectively, and the sample shape was transformed from a bar with a $\varnothing 25 \mathrm{~mm}$ diameter into a sheet with a width and thickness of $25 \mathrm{~mm}$ and $3 \mathrm{~mm}$, respectively. The bending radii $R_{1}, R_{2}$, the bending angles $\beta$ and $\psi$ were set to be $6 \mathrm{~mm}, 3 \mathrm{~mm}, 140^{\circ}$ and $100^{\circ}$, respectively.

In the present work, the AZ31-magnesium alloy with a composition of $3 \%$ mass fraction of $\mathrm{Al}, 1 \%$ mass fraction of $\mathrm{Zn}, 0.3 \%$ mass fraction of $\mathrm{Mn}$, and the $\mathrm{Mg}$ balance was employed. A graphite + engine oil lubrication containing a mass fraction of $70 \%$ of cylinder oil (74\#) and $30 \%$ of graphite (400 mesh) was sprayed on the specimens with a $25-\mathrm{mm}$ diameter and $30-\mathrm{mm}$ length, made from as-cast ingots and dies, to reduce the friction. Subsequently, the billet and die were heated to the target temperature for $10 \mathrm{~min}$, and the heated billet was promptly installed into the die to conduct the extrusion process for fabricating AZ31-magnesium-alloy sheets at $563 \mathrm{~K}$ and $643 \mathrm{~K}$.

The extrusion products were cut into a rectangle shape with dimensions of $6 \mathrm{~mm} \times 3 \mathrm{~mm} \times 8 \mathrm{~mm}$ along the longitudinal plane, as shown in Figure 1. The microstructures of the DEBS-ed sheets were examined from the extrusion-direction (ED), transverse-direction (TD) and normal-direction (ND) planes by means of optical microscopy, and the average grain size was measured using the linear intercept process. The central region of an extrusion product was chosen for an X-ray diffraction
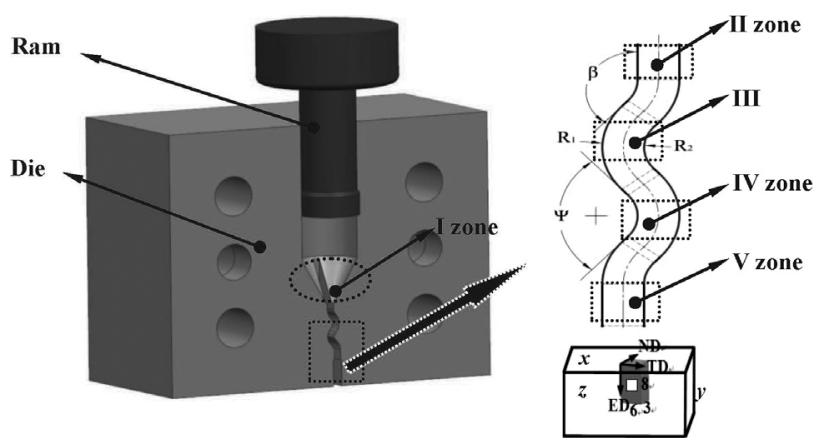

Figure 1: Sketch of the DEBS die and definition of external orientations; ED, TD, and ND denote the extrusion, transverse and normal directions
(XRD) analysis using a Bruker Discover equipment with $\mathrm{Cu}-K_{\alpha}$ radiation operated at $40 \mathrm{kV}$ and $40 \mathrm{~mA}$, and parameters $\alpha$ and $\beta$ were measured from $0^{\circ}$ to $75^{\circ}$ and $360^{\circ}$, respectively. Tensile tests were carried out using specimens with a gauge section of $25 \mathrm{~mm} \times 3 \mathrm{~mm} \times 10$ $\mathrm{mm}$ from the extruded sheets along the ED at room temperature and a constant velocity of $2 \mathrm{~mm} / \mathrm{min}$. Finally, the tensile-fracture surface was further analyzed with a scanning electron microscope. Besides, the microstructure and properties of the as-cast specimen were also tested for comparison.

\section{RESULTS AND DISCUSSION}

\subsection{Microstructure}

To examine the microstructure-refinement effect, the optical microstructures of the AZ31-Mg alloy before and after the extrusion are shown in Figures 2 and 3. The grains of the as-cast billet are coarse and the average grain size is calculated to be about $240 \mu \mathrm{m}$ (Figure 2a). Significantly, the DEBS-ed AZ31-magnesium-alloy sheet extruded at $563 \mathrm{~K}$ shows a prominent grain-refinement effect, and the average grain sizes obtained from the $x, y$ and $z$ planes are about $7.2 \mu \mathrm{m}, 4.5 \mu \mathrm{m}$ and $3.2 \mu \mathrm{m}$, respectively, as presented in Figures $\mathbf{2 b}$ to $\mathbf{2 d}$. After one pass, the originally coarse grains are refined markedly during the DEBS process, which is mainly attributed to the occurrence of DRX, triggered by a large accumulated strain during the extrusion process. In Figure $\mathbf{2 b}$, the microstructure consists of some coarse grains $(8 \mu \mathrm{m})$ in the local area, being surrounded by much finer grains $(2-4 \mu \mathrm{m})$. Even so, from an overall perspective, the grains are relatively homogeneously distributed and refined. It is obvious that the average grain size of the AZ31-magnesium alloy can be only reduced from 31.8 $\mu \mathrm{m}$ to $8 \mu \mathrm{m}$ after four ECAP passes at $573 \mathrm{~K}$ for rout $B_{\text {c. }}{ }^{14}$ In contrast, the DEBS process has a unique advantage and a potential for a grain refinement.

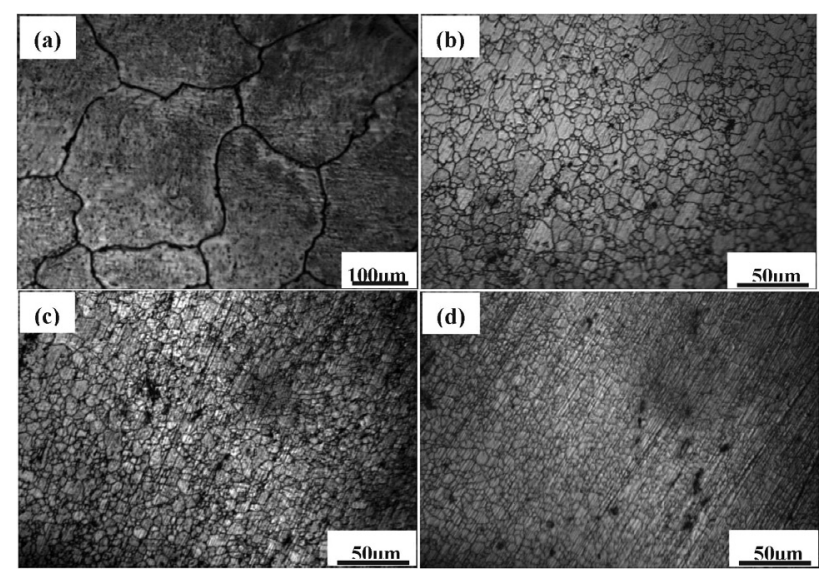

Figure 2: Optical microstructures of AZ31-Mg alloy before and after the DEBS process at $563 \mathrm{~K}$ : a) as-cast, b) to d) $x, y$ and $z$ planes of the extruded sample 
L. W. LU et al.: IMPROVING THE MICROSTRUCTURE AND MECHANICAL PROPERTIES OF MAGNESIUM-ALLOY ...
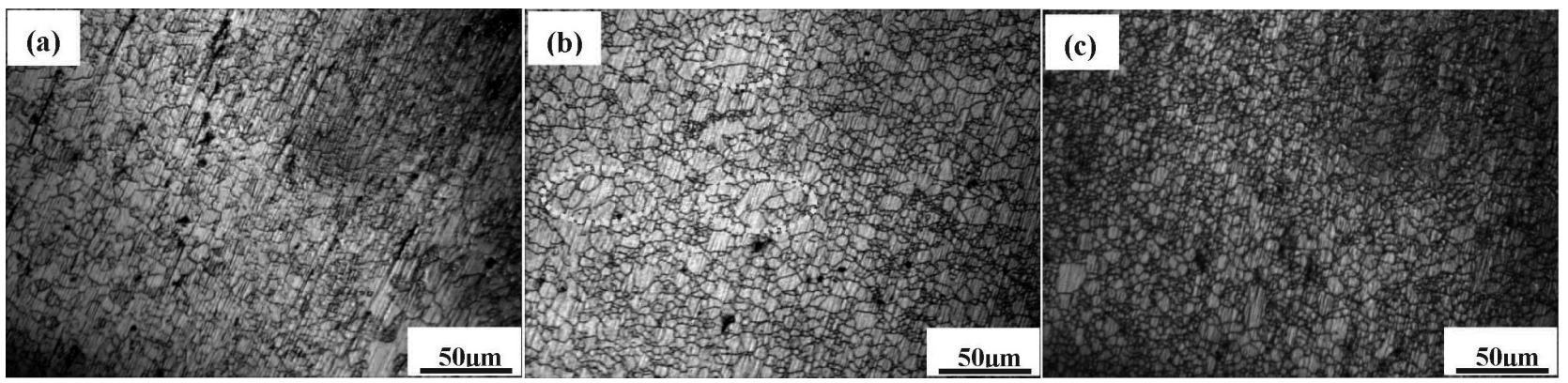

Figure 3: Light microstructures of DEBS-ed AZ31-Mg alloy at 643K: a)-c) $x, y$ and $z$ planes of the extruded sample

With an increase in the extrusion temperature $(643 \mathrm{~K})$, many tiny grains emerge (Figures 3a to $3 \mathbf{c}$ ). However, as there are still some inhomogeneously distorted grains in the local area, marked by ellipses (Figure 3b), there is not enough energy stored to fully complete DRX during the DEBS process, demonstrating that the extrusion temperature plays a significant role in the formation of distorted grains affected by the dislocation density, the evolution of dislocation cells and sub-structures. The aforementioned result is consistent with an earlier research result reported by J. F. Jiang et al. ${ }^{16}$ They also found that the mean grain size of 27.67 $\mu \mathrm{m}$ can be obtained with ECAP at $623 \mathrm{~K}$, which is much larger than that obtained at $643 \mathrm{~K}$ using DEBS.

\subsection{Textural evolution}

Figure 4 shows the $\{0002\}$ and $\{10 \overline{1} 0\}$ pole figures of the DEBS-ed sheets at different temperatures, exhibiting a typical $\{0002\}$ fiber texture after the DEBS process. However, in comparison with the conventional extrusion $(17.55)^{17}$, the texture intensity of the DEBS-ed sheets is significantly weakened (Figures $\mathbf{4 a}$ and $\mathbf{4 b}$ ) and

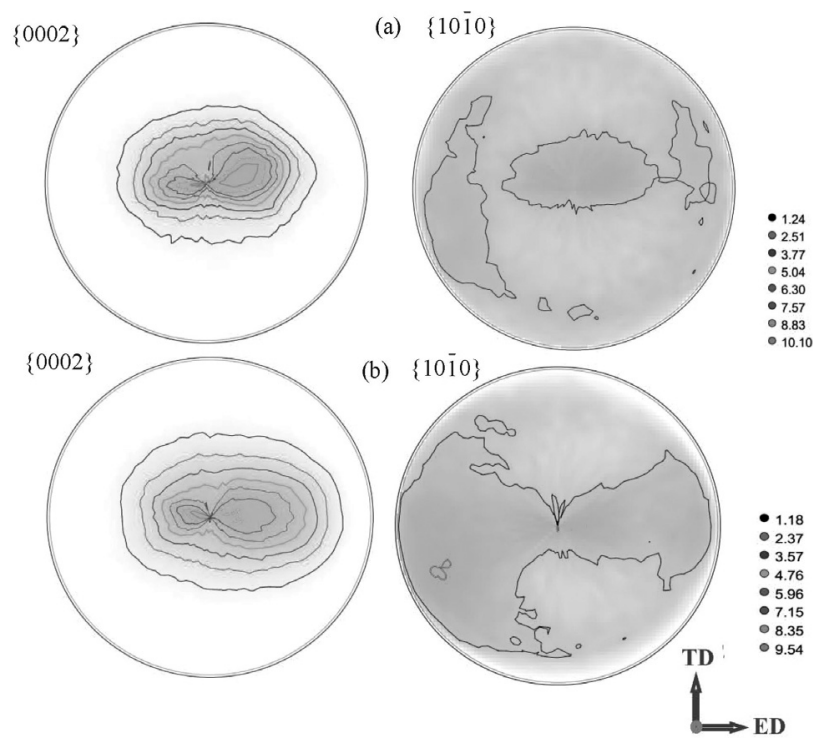

Figure 4: $\{0002\}$ and $\{10 \overline{1} 0\}$ pole figures for the DEBS-processed AZ31 alloys at different temperatures: a) $563 \mathrm{~K}$, b) $643 \mathrm{~K}$ the texture component becomes more dispersive along the ED, which can induce a good deformation capability due to the $\langle 11 \overline{2} 0>$ direction in fewer grains orientated parallel to the ED.

A closer observation reveals that the $\{0002\}$ pole figure forms a double-peaked basal texture characterized by a pronounced $\{0002\}$ basal plane tilted towards the $\mathrm{ED}$ at about $30^{\circ}$ and $13^{\circ}$ (Figure 4a), respectively, which may be a result of a larger shear strain accumulated by the bar-sheet deformation and continuous bending-shear deformation, activating more $<\mathrm{c}+\mathrm{a}>$ slip systems. These phenomena were previously reported for compressive shock loading and ARB processes by H. Asgari ${ }^{18}$ and H. Chang ${ }^{19}$, respectively. When the extrusion temperature increases to $643 \mathrm{~K}$, the $\{0002\}$ texture intensity decreases to 9.54, as shown in Figure $\mathbf{4 b}$, and the $\{0002\}$ basal plane tilts towards the ED at an angle of $10^{\circ}$, which is smaller than the one at $563 \mathrm{~K}$. The decrease in the basal texture intensity may be attributed to an increased activation of the non-basal slip at the higher temperature during the DEBS process.

\subsection{Mechanical properties}

To shed light on how the grain refinement and texture evolution affect the mechanical properties, tensile tests of the as-cast and DEBS-ed AZ31-Mg alloys are carried out at room temperature, and the tensile stress-strain pro-

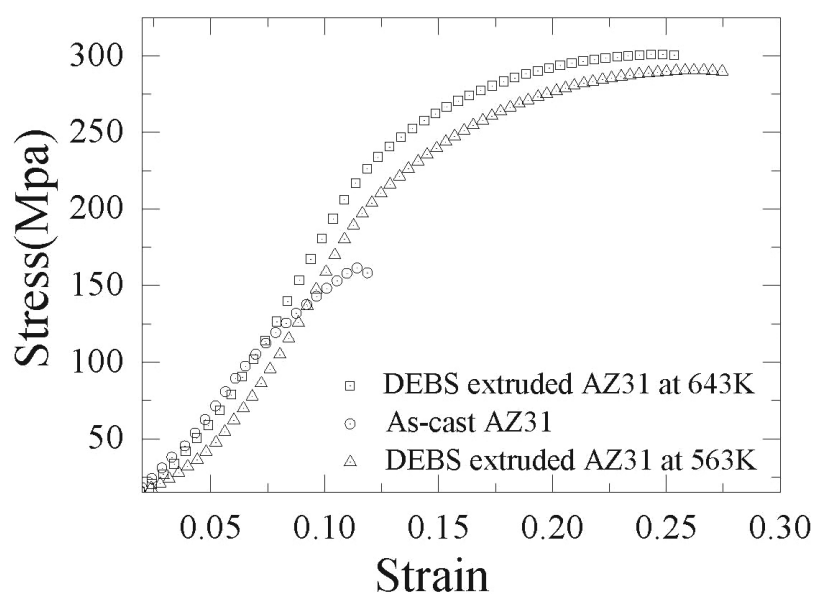

Figure 5: Tensile stress-strain curves at room temperature for the AZ31 samples processed with DEBS at $563 \mathrm{~K}$ and $643 \mathrm{~K}$ 
perties are shown in Figure 5. The yield strength (YS), ultimate tensile strength (UTS) and elongation of the as-cast AZ31-Mg alloy are 103.3 MPa, 163.6 MPa and $11.67 \%$, respectively, and they are mainly caused by the original coarse grains and casting defects. ${ }^{20}$ However, the mechanical properties are enormously enhanced with the DEBS process. As for the extrusion sheet at $563 \mathrm{~K}$, the YS and UTS are about $203 \mathrm{MPa}$ and $290 \mathrm{MPa}$, respectively. It should be noted that the elongation $(27.7 \%)$ is two times higher than that of the as-cast sample, which can be attributed to the combined effect of the weak basal texture and fine-grain size. It is well known that the weaker-texture intensity can lead to a larger Schmid factor of the $<a>$ basal slip, which can improve its ductility. ${ }^{21}$ When the processing temperature increases from $563 \mathrm{~K}$ to $643 \mathrm{~K}$, the YS and UTS are inversely increased to $220 \mathrm{MPa}$ and $300 \mathrm{MPa}$, respectively. There are some distorted grains with a high density of dislocation in the $643 \mathrm{~K}$ sample, which play an important role in improving the strength. However, the elongation decreases from $27.7 \%$ to $25.7 \%$, indicating that the grain refinement plays a dominant role in the enhancement of ductility. On the other hand, the tilt angle of the basal texture at $563 \mathrm{~K}$ is larger than that at $643 \mathrm{~K}$, as shown in Figures $\mathbf{4 a}$ and $\mathbf{4 b}$. Besides, the high density of dislocation and stress in the $643 \mathrm{~K}$ sample due to the accumulated distorted grains can also decrease its elongation.

The tensile fracture surface of an AZ31-alloy sheet before and after the DEBS process is presented in Figure 6. There are a large amount of cleavage planes, some shallow dimples and a few cracks in the fracture surface
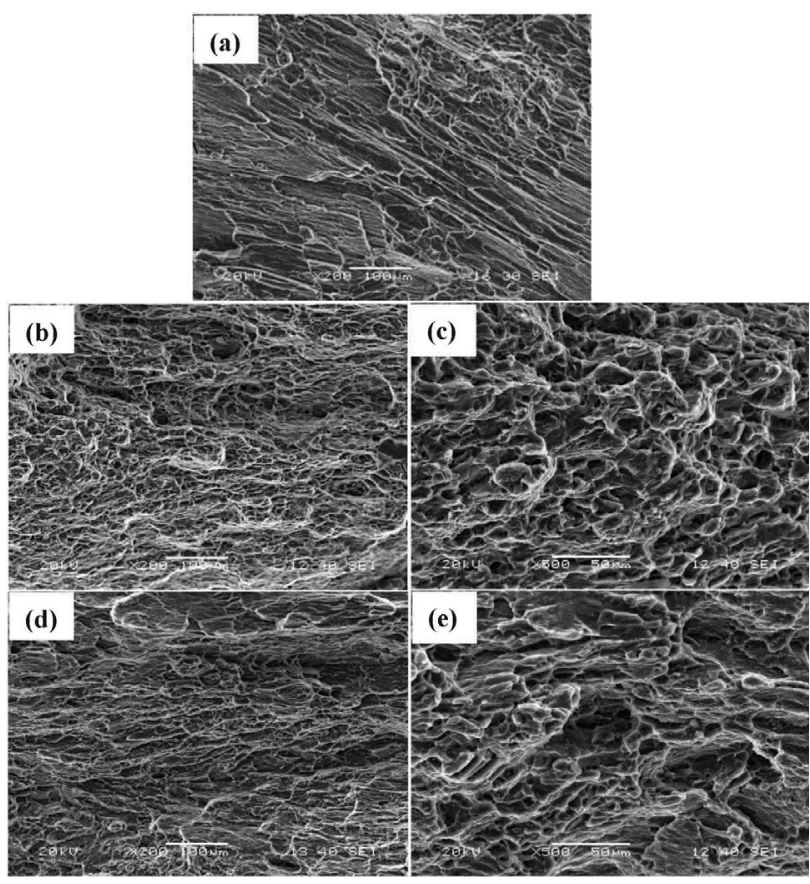

Figure 6: SEM images of the fracture surfaces of AZ31-Mg alloys before and after the DEBS process: a) as-cast, $200 \times$, b) and d) extruded at $563 \mathrm{~K}$ and $643 \mathrm{~K}, 200 \times$, c) and e) extruded at $563 \mathrm{~K}$ and $643 \mathrm{~K}, 500 \times$ of the as-cast AZ31-Mg alloy (Figure 6a), which are typical characteristics of a quasi-cleavage fracture. By comparison, many dimples emerge and become much deeper in the DEBS-ed AZ31-alloy sheet (Figure 6b), but when the extrusion temperature increases to $643 \mathrm{~K}$, the depth and number of dimples become shallower and fewer again (Figure 6d), indicating that the extrusion temperature plays an important role in tailoring the ductility.

Anyhow, the DEBS process can dramatically improve the plasticity and produce typical characteristics of a ductile fracture, which is mainly attributed to the tilted weak texture and grain refinement. A small-scale view of the tensile fracture surface can be seen in Figures $\mathbf{6 c}$ and 6e. There is almost no cleavage plane in Figure $\mathbf{6 c}$; however, some noticeable cleavage traces and inhomogeneous dimples are shown in Figure 6e, caused by some large local and inhomogeneously distributed grains. Therefore, to obtain refined and homogeneous microstructures and a titled weak basal texture, an advanced processing technology can be used as one of the most effective ways of modifying the plasticity of the $\mathrm{Mg}$ alloys important for engineering.

\section{CONCLUSION}

In summary, the DEBS technique was applied to fabricate an AZ31-magnesium-alloy sheet with high performance and we systematically investigated the grain refinement, texture evolution and mechanical properties of the processed alloy. We find that the average grain size of the as-cast AZ31 alloy is successfully refined from $240 \mu \mathrm{m}$ to $3.2 \mu \mathrm{m}$ at $563 \mathrm{~K}$; a crystallographic rotation and a weak texture are yielded after the DEBS process. Due to the combined effect of the grain refinement and texture weakening, both the plasticity and strength are dramatically improved. It is demonstrated that DEBS is a simple and highly efficient way of producing AZ31-alloy sheets with high performance.

\section{Acknowledgments}

This work was supported by the National Natural Science Foundation of China (Grant No. 51505143), the Scientific Research Fund of Hunan Provincial Education Department (Grant No. 17B089) and the China Postdoctoral Science Foundation (Grant No. 2016T90759 \& 2014M562128).

\section{REFERENCES}

${ }^{1}$ N. El Mahallawy, A. Ahmed Diaa, M. Akdesir, H. Palkowski, Effect of $\mathrm{Zn}$ addition on the microstructure and mechanical properties of cast, rolled and extruded Mg-6Sn-xZn alloys, Mater. Sci. Eng. A, 680 (2017), 47-53, doi:10.1016/j.msea.2016.10.075

${ }^{2}$ X. Xie, J. Shen, F. B. Gong, D. Wu, T. Zhang, X. Luo, Y. Li, Effects of dwell time on the microstructures and mechanical properties of water bath friction stir spot-welded AZ31 magnesium alloy joints, 


\section{MATERIALI IN TEHNOLOGIJE/MATERIALS AND TECHNOLOGY (1967-2017) - 50 LET/50 YEARS}

L. W. LU et al.: IMPROVING THE MICROSTRUCTURE AND MECHANICAL PROPERTIES OF MAGNESIUM-ALLOY ...

Int. J. Adv. Manuf. Technol., 82 (2016), 75-83, doi:10.1007/ s00170-015-7361-2

${ }^{3}$ H. F. Sun, C. J. Li, W. B. Fang, Evolution of microstructure and mechanical properties of $\mathrm{Mg}-3.0 \mathrm{Zn}-0.2 \mathrm{Ca}-0.5 \mathrm{Y}$ alloy by extrusion at various temperatures, J. Mater. Process. Tech., 229 (2016), 633-640, doi:10.1016/j.jmatprotec.2015.10.021

${ }^{4}$ L. C. Tang, C. M. Liu, Z. Y. Chen, D. W. Ji, H. C. Xiao, Microstructures and tensile properties of $\mathrm{Mg}-\mathrm{Gd}-\mathrm{Y}-\mathrm{Zr}$ alloy during multidirectional forging at $773 \mathrm{~K}$, Mater. Des., 50 (2013), 587-596, doi:10.1016/j.matdes.2013.03.054

${ }^{5}$ F. Akbaripanah, F. Fereshteh-Saniee, R. Mahmudi, H. K. Kim, Microstructural homogeneity, texture, tensile and shear behavior of AM60 magnesium alloy produced by extrusion and equal channel angular pressing, Mater. Des., 43 (2013), 31-39, doi:10.1016/ j.matdes.2012.06.051

${ }^{6}$ L. L. Tang, Y. H. Zhao, R. K. Islamgaliev, C. Y. A. Tsao, R. Z. Valiev, E. J. Lavernia, Y. T. Zhu, Enhanced strength and ductility of AZ80 Mg alloys by spray forming and ECAP, Mater. Sci. Eng. A, 670 (2016), 280-291, doi:10.1016/j.msea.2016.06.031

${ }^{7}$ J. Suh, J. Victoria-Hernández, D. Letzig, R. Golle, W. Volk, Effect of processing route on texture and cold formability of AZ31 Mg alloy sheets processed by ECAP, Mater. Sci. Eng. A, 669 (2016), 59-170, doi:10.1016/j.msea.2016.05.027

${ }^{8}$ W. Guo, Q. D. Wang, B. Ye, X. C. Li, X. C. Liu, H Zhou, Microstructural refinement and homogenization of $\mathrm{Mg}$-SiC nanocomposites by cyclic extrusion compression, Mater. Sci. Eng. A, 556 (2012), 267-270, doi:10.1016/j.msea.2012.06.086

${ }^{9}$ W. P. Yang, X. F. Guo, K. J. Yang, Low temperature quasi-superplasticity of ZK60 alloy prepared by reciprocating extrusion, Trans. Nonferrous Met. Soc. China, 22 (2012), 255-261, doi:10.1016/ S1003-6326(11)61168-0

${ }^{10}$ P. M. Bhovi, D. C. Patil, S. A. Kori, K. Venkateswarlud, Y. Huange, T. G. Langdon, A comparison of repetitive corrugation and straightening and high-pressure torsion using an Al-Mg-Sc alloy, J. Mater. Res. Technol., 5 (2016), 353-359, doi:10.1016/j.jmrt.2016.03.009

${ }^{11}$ M. P. Liu, H. J. Roven, X. T. Liu, M. Murashkin, R. Z. Valiev, T. Ungar, L Balogh, Grain refinement in nanostructured Al-Mg alloys subjected to high pressure torsion, J. Mater. Sci., 45 (2010), 4659-4664, doi:10.1007/s10853-010-4604-3

${ }^{12}$ M. H. Maghsoudi, A. Zarei-Hanzaki, H. R. Abedi, Modification of the grain structure, $\gamma$ phase morphology and texture in AZ81 Mg alloy through accumulative back extrusion, Mater. Sci. Eng. A, 595 (2014), 99-108, doi:10.1016/j.msea.2013.11.095

${ }^{13}$ G. Faraji, M. M. Mashhadi, H. S. Kim, Microstructure inhomogeneity in ultra-fine grained bulk AZ91 produced by accumulative back extrusion (ABE), Mater. Sci. Eng. A, 528 (2011), 4312-4317, doi:10.1016/j.msea.2011.02.075

${ }^{14}$ A. Muralidhar, S. Narendranath, H. Shivananda Nayaka, Effect of equal channel angular pressing on AZ31 wrought magnesium alloys, J. Magnesium Alloys, 1 (2013), 336-340, doi:10.1016/j.jma.2013. 11.007

${ }^{15}$ J. B. Lin, X. Y. Wang, W. J. Ren, X. X. Yang, Q. D. Wang, Enhanced strength and ductility due to microstructure refinement and texture weakening of the GW102K alloy by cyclic extrusion compression, J. Mater. Sci. Technol., 32 (2016), 783-789, doi:10.1016/j.jmst.2016. 01.004

${ }^{16}$ J. F. Jiang, Y. Wang, J. J. Qu, Microstructure and mechanical properties of AZ61 alloys with large cross-sectional size fabricated by multi-pass ECAP, Mater Sci. Eng. A, 560 (2013), 473-480, doi:10.1016/j.msea.2012.09.092

${ }^{17}$ L. W. Lu, C. M. Liu, Z. R. Yin, J. Zhao, L. Gan, Z. C. Wang, Double extrusion of Mg-Al-Zn alloys, Int. J. Adv. Manuf. Technol., 89 (2017), 869-875, doi:10.1007/s00170-016-9146-7

${ }^{18}$ H. Asgari, A. G. Odeshi, J. A. Szpunar, L. J. Zeng, E. Olsson, Grain size dependence of dynamic mechanical behavior of AZ31B magnesium alloy sheet under compressive shock loading, Mater. Charact., 106 (2015), 359-367, doi:10.1016/j.matchar.2015.06.030

${ }^{19}$ H. Chang, M. Y. Zheng, W. M. Gan, K. Wu, E. Maawad, H. G. Brokmeier, Texture evolution of the $\mathrm{Mg} / \mathrm{Al}$ laminated composite fabricated by the accumulative roll bonding, Scripta Mater., 61 (2009) 7 , 717-720, doi:10.1016/j.scriptamat.2009.06.014

${ }^{20}$ W. Guo, Q. D. Wang, B. Ye, H. Zhou, Microstructure and mechanical properties of AZ31 magnesium alloy processed by cyclic closed-die forging, J. Alloys Compd., 558 (2013), 164-171, doi:10.1016/j.jallcom.2013.01.035

${ }^{21}$ Q. S. Yang, B. Jiang, H. C. Pan, B. Song, Z. T. Jiang, J. H. Dai, L. F. Wang, F. S. Pan, Influence of different extrusion processes on mechanical properties of magnesium alloy, J. Magnesium Alloys, 2 (2014), 220-224, doi:10.1016/j.jma.2014.10.001 